INTERNATIONAL JOURNAL OF MULTIDisciplinARY RESEARCH AND ANALYSis

ISSN(print): 2643-9840, ISSN(online): 2643-9875

Volume 04 Issue 07 July 2021

DOI: 10.47191/ijmra/v4-i7-16, Impact Factor: 6.072

Page No.- $986-998$

\title{
Insurance Sector Development and Economic Growth in Nigeria, $1980-2014$
}

\author{
Makwe, Emmanuel Uzoma (Ph.D) ${ }^{1}$, Ibechiole, Onyekachi Chikamnele ${ }^{2}$, \\ Obiaga, Johnson Chinedu (Ph.D) ${ }^{3}$
}

${ }^{1}$ Department of Finance and Banking, Faculty of Management Sciences, University of Port Harcourt, Rivers State, Nigeria

${ }^{2}$ Department of Banking and Finance, Faculty of Management Sciences, Nnamdi Azikiwe University, Awka, Anambra State, Nigeria

${ }^{3}$ Department of Accounting and Finance, Faculty of Humanities, Social and Management Sciences, Edwin Clark University, Kiagbodo, Delta State, Nigeria

\begin{abstract}
This study was carried out to determine the effect of insurance sector development on the economic growth of Nigeria. Consequently, three hypotheses were designed to guide the researcher and data were drawn from the Central Bank of Nigeria (CBN) statistical bulletin which covered a thirty five (35) years period between 1980 to 2014 . The hypotheses were tested using ordinary least square regression analysis and the econometrics co integration test and the result revealed that; there is a positive and significant relationship between insurance premium and economic growth in Nigeria; there is a positive and significant relationship between insurance claims and gross domestic product of Nigeria; there is a positive and significant relationship between insurance investments and economic growth in Nigeria. Based on the results, the researcher thus recommended the following amongst others; Government should Provide institutional improvements by making better laws and policies that will not only encourage fair play but also help to attract international players in the industry; Government should also provide information and education to the populace on the importance of acquiring insurance cover in order to be protected; Increasing efficiency, especially in risk management, and product development.
\end{abstract}

KEYWORDS: Insurance; Insurance sector development; Premiums; Insurance claims; Insurance investments; Gross domestic products; Economic growth.

\subsection{INTRODUCTION}

Considerable attention has been devoted to evaluating the relationship between economic growth and financial market deepening. Most of what we have learned relates to banking systems and securities markets, with insurance receiving only a passing mention. Yet, while insurance, banking, and securities markets are closely related, insurance fulfils somewhat different economic functions than do other financial services, and in turn requires particular conditions to flourish and to make a full economic contribution (Brainard, 2008).

The size and maturity of the insurance industry is one of the indices used for measuring the development of an economy. This is because the insurance industry plays a very important role in the mobilisation and utilization of investable resources in an economy. It also acts as the absorber of the risks and uncertainties normally associated with economic activities, the absence of a market which can greatly reduce the growth of economic activity.

The relevance of the insurance industry is even more evident in such less-developed economies as Nigeria where the financial system is not very sophisticated and where there is lack of basic infrastructure required to aid the growth of the economy (Abdulmalik, 2009). This gives rise to the dependence of Nigeria's economy on those of the developed countries' balance of payments.

In Nigeria, prior to the mid-seventies, the insurance industry was dominated by foreign insurance companies, this meant that the premium paid for insurance placed with these companies were transmitted overseas, thus putting so much pressure on the country's balance of payments. With the indigenization of the insurance industry in the early seventies and the promulgation of 


\section{Insurance Sector Development and Economic Growth in Nigeria, 1980 -2014}

the Insurance Decree of 1976, the activities of the industry were streamlined to enable it have enough retention capacity and thereby to play a critical role in the development of the economy (Abdulmalik, 2009)

Insurance and economic growth mutually influences each other, as the economy grows, the living standards of people increase and as a result, the demand for insurance increases. As the assets of people and of business enterprises increase in the growth process, the demand for general insurance also increases (Akinlo \& Apanisile, 2014). In fact, as the economy widens the demand for new types of insurance products emerges. Insurance is no longer confined to product markets; they also cover service industries. It is equally true that growth itself is facilitated by insurance. A well-developed insurance sector promotes economic growth by encouraging risk-taking.

Risk is inherent in all economic activities and without some kind of cover against risk, some of these activities will not be carried out at all. Also insurance and more particularly life insurance is a mobilizer of long term savings and life insurance companies are thus able to support infrastructure projects which require long term funds. There is thus a mutually beneficial interaction between insurance and economic growth (Cristea, Marcu \& Carstina, 2014).

The deepening of insurance markets makes a positive contribution to economic growth, while life insurance is causally linked to growth only in higher income economies; nonlife insurance makes a positive contribution in both developing and higher income economies (Ndalu, 2016).

This research is aimed at establishing the link between insurance development and economic growth in Nigeria, 1980 - 2014.

\subsection{Objectives}

1. To examine the effect of insurance premium on economic growth in Nigeria

2. To determine the effect of insurance claims on the gross domestic product of Nigeria

3. To evaluate the effect of insurance investments on economic growth in Nigeria

\subsection{Hypotheses}

There is no significant relationship between insurance premium and economic growth in Nigeria There is no significant relationship between insurance claims and gross domestic product of Nigeria There is no significant relationship between insurance investments and economic growth in Nigeria

\subsection{SYNOPSIS OF CONCEPTUAL AND EMPIRICAL LITERATURE}

\subsection{Conceptual Review}

Insurance is understood by most people to be critical to a well-functioning economy (Olayungbo \& Akinlo, 2016). By providing payment in the event of unexpected losses, insurance introduces security into personal and business situation. It also serves as a basis of credit as no financial institution would lend money for purchase of capital goods.

Evidence suggests that insurance contributes materially to economic growth by improving the investment climate and promoting a more efficient mix of activities than would be undertaken in the absence of risk management instruments (Brainard, 2008). This contribution is magnified by the complementary development of banking and other financial systems.

Empirical studies suggest that nonlife insurance contributes to growth in a country at many different levels of development. Life insurance makes a substantial contribution to growth mostly in wealthier countries, since life insurance is typically a smaller part of the total insurance market in low income countries (Brainard, 2008).

The relationship between per capita income levels and insurance penetration is also strong in the reverse direction- with rising income a strong driver of life insurance coverage. However, it is difficult to disentangle whether lower insurance consumption at lower income levels reflects reduced demand for life insurance products or constraints on the supply side associated with weak regulatory and supervisory environments and high costs of insurance provision (Richterkova \& Korab, 2013).

Of course, even if the data did not support a strong causal role for insurance as an engine of overall aggregate growth, there might be a strong case for insuring the poor on social welfare grounds that those at or below the poverty line are particularly vulnerable to catastrophic shocks to income and consumption.

Indeed, it appears that the gap between the potential social value of insurance and the transactions costs of provision might be unusually wide for the poorest segment of society, which explains the growing interest in micro-insurance on the part of nongovernmental organizations and philanthropic foundations, some of whom are partnering with commercial providers.

Yinusa and Akinlo (2013), posited that, insurance serves a number of valuable economic functions that are largely distinct from other types of financial intermediaries. In order to highlight specifically the unique attributes of insurance, it is worth focusing on those services that are not provided by other financial services providers, excluding for instance the contractual savings features of whole or universal life products. The indemnification and risk pooling properties of insurance facilitate commercial 


\section{Insurance Sector Development and Economic Growth in Nigeria, 1980 -2014}

transactions and the provision of credit by mitigating losses as well as the measurement and management of non diversifiable risk more generally.

Typically insurance contracts involve small periodic payments in return for protection against uncertain, but potentially severe losses. Among other things, this income smoothing effect helps to avoid excessive and costly bankruptcies and facilitates lending to businesses (Zouhaier, 2014).

Most fundamentally, the availability of insurance enables risk averting individuals and entrepreneurs to undertake higher risk, higher return activities than they would do in the absence of insurance, thus promoting higher productivity and growth.

\subsubsection{Insurance Business and Economic Growth}

One of the indices for measuring the development of an economy is the size and maturity of its insurance industry. This is because the insurance industry plays a very important role in the mobilisation and utilization of investible resources in an economy. It also acts as the absorber of the risks and uncertainties normally associated with economic activities, the absence of a market which can greatly reduce the growth of economic activity (Akinlo \& Apanisile, 2014).

Yinusa and Akinlo, (2013) declared that, the relevance of the insurance industry is even more evident in such less-developed economies as Nigeria where the financial system is not very sophisticated and where there is lack of basic infrastructure required to aid the growth of the economy. This gives rise to the dependence of Nigeria's economy on those of the developed countries' balance of payments.

In Nigeria, prior to the mid-seventies the insurance industry was dominated by foreign insurance companies. This meant that the premium paid for insurance placed with these companies were transmitted overseas, thus putting so much pressure on the country's balance of payments (Yinusa \& Akinlo, 2013).

With the indigenization of the insurance industry in the early seventies and the promulgation of the Insurance Decree of 1976, the activities of the industry were streamlined to enable it to have enough retention capacity and thereby to play a critical role in the development of the economy. Since then, the industry has been playing a very useful role in the economy, most notably in the areas highlighted below.

a) Reduction in the outflow of resources from the country through the retention of insurance and reinsurance premiums within the economy, with a consequent positive effect on the country's balance of payments.

b) Development of the capital market. The insurance industry constitutes one of the major institutional investors in the capital market, thereby providing a channel for the sourcing of funds by both the public and private sectors of the economy.

c) Cultivating insurance consciousness. The advent of an organized insurance industry and the activities of its members have greatly improved the cultivation of insurance consciousness among business houses and individuals. This has reduced the level of risk which generally encouraged enterprises and therefore enhanced the growth of the economy.

d) Direct equity and loan investment in industrial enterprises. The industry is a major catalyst in the development of large industrial undertakings which are highly capital intensive.

e) Mobilisation of savings. The activities of the industry particularly life assurance business have encouraged the mobilisation of savings which otherwise may not have been channeled to any productive use. Such mobilized savings constitute an important source of long-term investible funds in the economy.

In fact, the Nigerian insurance industry has grown over the years to become second only to banking, an important vehicle for the mobilisation and use of funds. Figures available on the paid up capital and free reserves of all insurance companies in the country indicate that the retention capacity of the industry has been on the increase, with a consequent positive impact on the development of the economy (Akinlo \& Apanisile, 2014).

It is apparent from the foregoing that the insurance industry has become a significant contributor to the overall development before the industry can achieve its full potential for the development of the economy. Examples of areas of untapped potential include product diversification and packaging, effective portfolio management and investment practices, effective marketing, manpower development, the improvement of the image of insurance among the populace, and investment in research (Abdulmalik, 2009).

\subsection{Empirical Review}

There have been numerous studies carried out to investigate the relationship between the insurance sub-sector and the economy. Curak, loncar and Poposki (2009), observed that providing protection to insurers could affect economic growth through the channels of marginal productivity of capital, technological innovations and saving rate. Insurance companies indemnify the ones who suffer a loss and stabilize the financial position of individuals and firms. 


\section{Insurance Sector Development and Economic Growth in Nigeria, 1980 -2014}

Devereux and Smith (1994) observed that diversification could negatively affect economic growth through lowering saving rate. Namely, it is possible that the lower risk resulted from diversification may induce individuals to save less.

Ward and Zurbruegg (2000) examined the causal relationship between growth in insurance activity and economic growth for nine OECD countries during the period from 1961 to 1996. In the same vein, Webb, Grace and Skipper, (2005), analyzed the effect of banking and insurance on the growth of capital and output based on cross-country data of 55 countries for the period from 1980 to 1996 . The insurance variable is measured by average insurance penetration (insurance premiums relative to GDP) of life and non-life insurance respectively. At the first stage they use ordinary least squares estimation method, while at the later one an iterated three stage least squares simultaneous estimation was employed. The results of the first estimation, assuming exogenous financial variables, indicate positive effect of banking development on economic growth, while insurance variables do not enter significantly.

\subsection{METHODOLOGY}

The Quasi-experimental research design was adopted because the relationship existing between the variables involved a dependent variable and independent variables.

\subsection{Sampling Procedure}

To test the hypotheses drawn for this study, the OLS of multiple linear regression model will be used in estimating the values of the variables. The regression model used is based on its possession of the BLUE properties, making it the best for the type of data used in the study.

\subsection{Data Collection Method}

Secondary data was used. These were gotten from the annual publications of the CBN.

\subsection{Model Specification}

Using the regression formula $y=a--b x_{1}+e_{i}$, the variables will be represented using symbols and notations. The models are presented in the functional and mathematical forms. This is given by the formula:

$G D P=f(P, C, I)$

$G D P=a+b_{1} P+b_{2} C+b_{3} l+U_{i}$

Where GDP = the dependent variable,

$\mathrm{P}=$ the independent or explanatory variable;

$\mathrm{C}=$ the insurance Claims

$I=$ the total investments in the insurance subsector

$a=$ slope

$b=$ coefficient of the independent or explanatory variables and

$\mathrm{U}_{1}=$ stochastic term

\subsection{Data Analysis}

The data will be analyzed using the a priori tests, statistical and econometric tests. Further, stationarity analysis will be conducted using the Augmented Dickey-Fuller (ADF) test, Granger Causality tests, and Normality Tests. If need be, the second other test will be conducted using the Johansen Cointegration Tests, Error Correction Mechanism to correct for the short-run relationship of the variables. All analysis will be conducted using the Eviews version 7.0 software.

\subsection{PRESENTATION AND ANALYSIS OF DATA}

The following table shows the various data collected for the purpose of analyzing the hypotheses drawn. It also shows the relationship between the variables to be analyzed.

\begin{tabular}{ll|lll} 
Year & GDP & Premiums & Claims & Investments \\
1980 & 87.88 & 179569 & 61.3 & NA \\
1981 & 94.33 & 234.1 & 74.2 & NA \\
1982 & 101.01 & 248.8 & 79.2 & NA \\
1983 & 110.06 & 191.8 & 78.6 & NA \\
1984 & 116.27 & 205.7 & 77.7 & NA \\
1985 & 134.59 & 195.3 & 64.0 & NA \\
1986 & 134.60 & 254.2 & 86.4 & NA
\end{tabular}


Insurance Sector Development and Economic Growth in Nigeria, 1980 -2014

\begin{tabular}{|c|c|c|c|c|}
\hline 1987 & 193.13 & 406.5 & 109.4 & NA \\
\hline 1988 & 263.29 & 486.6 & 151.1 & NA \\
\hline 1989 & 382.26 & 673.1 & 278.9 & NA \\
\hline 1990 & 472.65 & $1,013.7$ & 306.5 & NA \\
\hline 1991 & 545.67 & $1,296.2$ & 386.9 & NA \\
\hline 1992 & 875.34 & $2,445.7$ & 613.9 & NA \\
\hline 1993 & $1,089.68$ & $4,931.9$ & $2,684.1$ & NA \\
\hline 1994 & $1,399.70$ & $14,519.1$ & $1,315.3$ & NA \\
\hline 1995 & $2,907.36$ & $13,525.1$ & $1,508.9$ & NA \\
\hline 1996 & $4,032.30$ & $11,091.3$ & $1,654.1$ & $12,379.5$ \\
\hline 1997 & $4,189.25$ & $10,941.6$ & $1,677.3$ & $13,613.1$ \\
\hline 1998 & $3,989.45$ & $11,688.3$ & $1,956.2$ & $15,656.9$ \\
\hline 1999 & $4,679.21$ & $14,597.3$ & $5,923.2$ & $21,583.5$ \\
\hline 2000 & $6,713.57$ & $22,531.5$ & $5,629.5$ & $25,192.6$ \\
\hline 2001 & $6,895.20$ & $28,981.3$ & $6,110.5$ & $32,157.3$ \\
\hline 2002 & $7,795.76$ & $37,765.9$ & $6,856.1$ & $36,940.9$ \\
\hline 2003 & $9,913.52$ & $43,441.8$ & $9,415.2$ & $54,642.8$ \\
\hline 2004 & $11,411.07$ & $50,100.8$ & $12,084.0$ & $74,590.8$ \\
\hline 2005 & $14,610.88$ & $67,465.6$ & $12,402.4$ & $121,844.2$ \\
\hline 2006 & $18,564.59$ & $81,583.8$ & $76,276.1$ & $216,359.9$ \\
\hline 2007 & $20,657.32$ & $89,104.9$ & $15,843.7$ & $329,247.9$ \\
\hline 2008 & $24,296.33$ & $126,470.3$ & $25,864.9$ & $336,491.4$ \\
\hline 2009 & $24,794.24$ & $153,127.1$ & $49,498.9$ & $343,894.2$ \\
\hline 2010 & $54,612.26$ & $157,336.8$ & $37,589.6$ & $351,459.9$ \\
\hline 2011 & $62,980.40$ & $175,756.8$ & $39,389.2$ & $359,192.0$ \\
\hline 2012 & $71,713.94$ & $112,900.8$ & $31,944.4$ & $388,615.9$ \\
\hline 2013 & $80,092.56$ & $117,693.8$ & $33,303.9$ & $417,090.9$ \\
\hline 2014 & $89,043.62$ & $122,486.8$ & $34,663.3$ & $445,566.0$ \\
\hline
\end{tabular}

Source: CBN Statistical Bulletin, 2014

\subsection{Data Presentation and Testing of Hypotheses}

\subsubsection{First order test: Regression analysis}

GDP $=-551.2195-90.78009 P-0.272376 C+0.157707 \mid$

t-values $(-0.250005)(-0.902748)(-2.316710) \quad(6.519485)$

$R^{2}=0.881808 ; F=50.36053 ;$ Durbin-Watson $=0.644788$

The regression analysis shows that $\mathrm{R}^{2}$ is high with some insignificant $t$-values. The goodness-of-fit shows that $88 \%$ of the changes the dependent variable are explained by the changes in the independent variables. More so, the $f$-test shows that the model is significant when taken together while Durbin-Watson shows the presence of serial autocorrelation. The result is spurious regression with $\mathrm{R}^{2}$ being greater than Durbin-Watson.

\subsubsection{Normality Test: Jarque-Bera Test}

A normality test is used to determine whether sample data has been drawn from a normally distributed population (within some tolerance). This means that the population for the study is not skewed towards a particular angle. If the $p<0.05$, we reject the null hypothesis that a variable is not normality distributed otherwise, we accept the null hypothesis. The result shows that all the other variables are normally distributed except interest rate with a probability value of 0.101463 .

\subsubsection{Augmented Dickey-Fuller Tests}

As one of the tests for unit roots, ADF tests whether the variables are stationary or not that is, whether their means and variances are the same over time. If they are not stationary, there is need to lag the variables in order to obtain a stationary time series. Stationarity occurs when the ADF values are greater than the critical values or the $t$-value is significant.

The results shows that GDP, Premium and Claims variables were stationary both at first differencing as the ADF values are higher than their critical values at $5 \%$ level. However, total investments were found to be non-stationary. Cointegration analysis 


\section{Insurance Sector Development and Economic Growth in Nigeria, 1980 -2014}

requires that two or more variables must be stationary for the analysis. This is the condition required for conducting a Johansen Cointegration Test. The ADF test result is shown in the table below:

Table 4.2.2.1 Table showing ADF Values at first differencing.

$\begin{array}{llll}\text { Coefficients } & \text { t-test } & \text { Probability } & \text { Status } \\ \text { GDP } & 4.971207 & 0.0001 & \text { Stationary } \\ \text { I } & 0.201624 & 0.8420 & \text { Non Stationary } \\ \text { P } & 2.320325 & 0.0295 & \text { Stationary } \\ \text { C } & -5.825459 & 0.0000 & \text { Stationary }\end{array}$

Computed by the researcher using E-view 7.0

\subsubsection{Granger Causality Test}

The relationship between two variables does not necessarily determine the causality between the variables. Therefore, the Granger Causality Test, as shown in the appendix, tests the direction of cause that may exist between the variables used in the analysis. The result shows that Assets, Premium, and Claims granger cause GDP. This is determined by the f-value which is more than the rule of thumb of 2.

\subsubsection{Co-integration Test}

The cointegration test, as pointed out by Gujarati (2004), is a pre-test that shows whether the variables have a long-term relationship or not. This establishes whether we will be using the variables together or not performing the ECM. The cointegration analysis must have two cointegrating equations based on the probability so as to validate it for ECM analysis. Therefore, the Johansen Cointegration Test using the value of the Trace Statistic values reveals that the variables are cointergated at levels down to the third equation. They have a long-term relationship. The model shows that there are at least two cointegrating equations which is a prerequisite for conducting the Error Correction Mechanism.

Unrestricted Cointegration Rank Test (Trace)

\begin{tabular}{lllll}
\hline \hline $\begin{array}{l}\text { Hypothesized } \\
\text { No. of CE(s) }\end{array}$ & Eigenvalue & $\begin{array}{l}\text { Trace } \\
\text { Statistic }\end{array}$ & $\begin{array}{l}0.05 \\
\text { Critical Value }\end{array}$ & Prob.** \\
\hline \hline None ${ }^{*}$ & 0.988129 & 239.3769 & 69.81889 & 0.0000 \\
At most 1 & 0.920534 & 124.1017 & 47.85613 & 0.0000 \\
At most 2 & 0.798822 & 58.25868 & 29.79707 & 0.0000 \\
At most 3 & 0.446502 & 16.56600 & 15.49471 & 0.0344
\end{tabular}

Trace test indicates 4 cointegrating eqn(s) at the 0.05 level

* denotes rejection of the hypothesis at the 0.05 level

**MacKinnon-Haug-Michelis (1999) p-values

Source: Eviews 7.0

\subsection{Parsimonious Error Correction Mechanism (Long-run Analysis)}

This corrects the short-term analysis of cointegration test. As the cointegration test examines the long-term relationship between variables, the ECM corrects the short-term relationship between the variables. It is expected that the variables obey the a priori signs while the ECM has a negative sign.

$\mathrm{GDP}=0.042386+0.206337 \mathrm{P}+7.110037 \mathrm{C}+22.86337 \mathrm{I}$

$\mathrm{t}$-value $=(1.522733)$ (2.687151) (2.755387) (5.672111)

$\mathrm{f}$-value $=2.541602$

$R^{2}=0.828304$

Durbin-Watson $(\mathrm{d})=2.825260$

$\operatorname{ECM}(-1)=-3.552390$

In the long-run analysis conducted, the result shows that $R^{2}=0.83$ which indicates that $83 \%$ of the changes in the dependent variable (GDP) are explained by the changes in the independent variables. 


\section{Insurance Sector Development and Economic Growth in Nigeria, 1980 -2014}

Further, the f-test of 2.54 shows that the variables are significant when taken together at $5 \%$ level of significance using the rule of thumb (2) while the Durbin-Watson (d) statistic equally shows an absence of serial autocorrelation of the first order at the value of 2.825260 .

Again, the ECM is correctly signed while the variables appear with the right signs as well as being significant at $5 \%$ level of significance.

\subsection{Testing the hypotheses}

The above results using the ECM values shows that we will reject the null hypotheses and accept the alternative hypotheses and conclude that there is a significant relationship between insurance subsector development and economic growth of Nigeria, 1980 -2014. Thus, the authorities involved should use viable means to encourage the operations of the insurance subsector in Nigeria. As observed, the positive changes in Premium, Claims and Investments have positive impact on the economic growth of the country, although in a small measure. However, with conscious and sustained efforts, the government can improve on these results.

\subsection{CONCLUSION AND RECOMMENDATIONS}

\subsection{Conclusion}

The study examined the link between the development of the Insurance industry in Nigeria and economic growth. The results obtained indicated that a relationship exist between insurance premiums, claims and investments and the development of the Nigerian economy.

Data examined also indicate that even though the industry has developed significantly since inception, it is still very small in comparison to the insurance industry of other developing countries like South Africa and Brazil. This has meant that the industry is unable to provide adequate cover for businesses in the country especially the multinationals that prefer to take their insurance business abroad.

\subsection{Recommendations}

On the basis of the research findings, it is necessary to attempt to make recommendations for the policy options of the government. Thus, we make the following recommendations.

i. Providing institutional improvements by making better laws and policies that will not only encourage fair play but also help to attract international players in the industry. By also making sure that policies are implemented. These will positively impact on the key insurance variables that have positive impacts on the GDP of Nigeria.

ii. Provide information and education to the populace on the importance of acquiring insurance cover in order to be protected. This will not only provide more business for insurance companies but also encourage businesses to engage in more businesses that they could have viewed as being too risky. This has become risky as more people become averse to taking up insurance policies due to the bureaucratic bottle-necks associated with claims.

iii. Encouraging competition should be an important goal for regulators of the sector. This can be done not necessarily by increasing the number of players in the industry, but by encouraging players to increase the size of the companies. This will not only provide better cover for the insured but also inspire confidence in the industry.

iv. Increasing efficiency, especially in risk management, and product development

\section{REFERENCES}

1) Abdulmalik, Muye (2009): Insurance and the Nigerian economy http ://themarketrnagazi ne corn)

2) Akinlo, T., \& Apanisile, O. T. (2014). Relationship between insurance and economic growth in Sub-Saharan African: A panel data analysis. Modern Economy, 05(02), 120-127. doi:10.4236/me.2014.52014 [Crossref], [Google Scholar]

3) Baridam, M.D. (2001): Research Methods in Administrative Sciences, Sherbrooke Associates, Port Harcourt.

4) Brainard, L. (2008). What is the role of insurance in economic development? Retrieved from https://www.draudimas.com/allpics/What is the role of economic developement.pdf

5) CENTRAL BANK Of NIGERIA, The Bullion, (2015): Budget of Economic growth and development, Central Bank of Nigeria, Abuja

6) Cristea, M., Marcu, N., \& Carstina, S. (2014). The relationship between insurance and economic growth in Romania compared to the main results in Europe-A theoretical and empirical analysis. Procedia Economics and Finance, 8, 226235.

7) Curak, M., Loncar, S. \& Poposki, K., (2009). Insurance sector development and economic growth in transition countries. International Research Journal of Finance and Economics 34:29-41 


\section{Insurance Sector Development and Economic Growth in Nigeria, 1980 -2014}

8) Devereux, M.B.,\&Smith, G.W. (1994). International risk sharing and economic growth. International Economic Review, 35(4),535-550.https://doi.org/10.2307/2527072

9) Gujarati, D.N. (2004) Basic Econometrics. 4th Edition, McGraw-Hill Companies.

10) Ndalu, C. (2016). Financial deepening of insurance and economic growth in Kenya. International Journal of Academic Research in Accounting, Finance and Management Sciences, 6(1), 7-14.

11) Olayungbo, D. O., \& Akinlo, A. E. (2016). Insurance penetration and economic growth in Africa: Dynamic effects analysis using Bayesian TVPVAR approach. Cogent Economics \& Finance, 4, 1-19.

12) Richterkova, Z., \& Korab, P. (2013). Impact of insurance sector activity on economic growth -A meta analysis. Acta Universitatis Agriculturae et Silviculturae Mendelianae Brunensis, 61(7), 2677-2683.

13) Usman, 0. A (2009): Scale Economies and Performance Evaluation of Insurance Market in Nigeria, Medwell Journal of Social Sciences, vol 4 (1), Medwell publishing.

14) Ward D. and R. Zurbruegg, (2000): “Does Insurance Promote Ecncrni Growth? Evidence from OECD Countries", Journal of Rsk a. Insurance, 67 (4), pp. 489-506.

15) Webb, I. M.F. Grace, and H. Skipper, (2005): The Effect of' Banking and Insurance on the Growth of Capital and Output, Journal of Financial Issues) 2(2), pp. 1-32.

16) Yinusa, O., \& Akinlo, T. (2013). Insurance development and economic growth in Nigeria, 1986-2010. Journal of Economics and International Finance, 5(5), 218-224. doi:10.5897/JEIF2013.0498

17) Zouhaier, H. (2014). Insurance and economic growth. Journal of Economics and Sustainable Development, 5(12), 102112.

\section{APPENDIX}

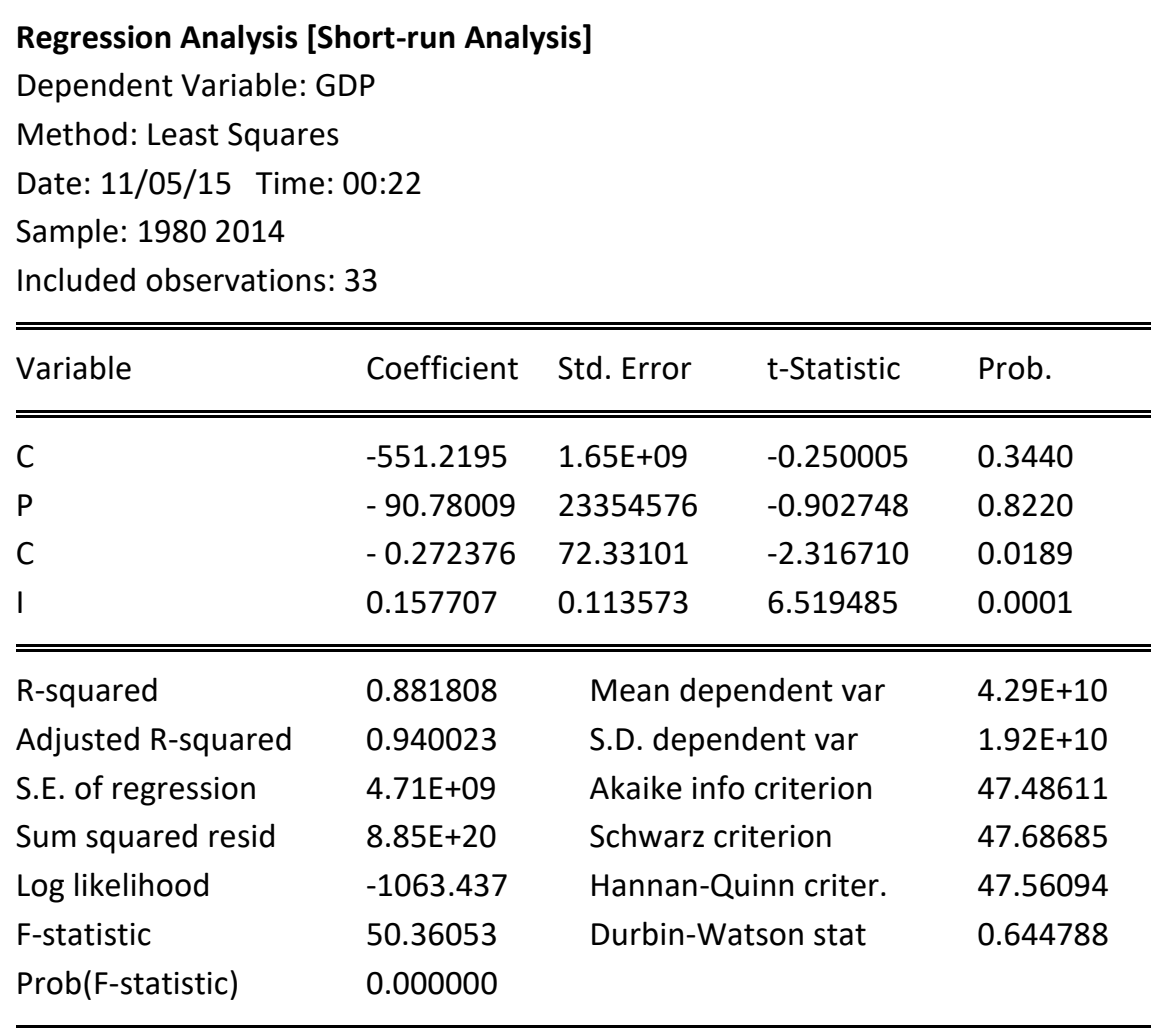

Source: Computed from EView 7.0 (2016)

Augmented Dickey-Fuller Test

Null Hypothesis: D(GDP) has a unit root

Exogenous: Constant

Lag Length: 0 (Automatic - based on SIC, maxlag=8)

\begin{tabular}{llc}
\hline \hline & t-Statistic & Prob.* \\
\hline \hline Augmented Dickey-Fuller test statistic & -3.04811 & 0.0019 \\
\hline
\end{tabular}


Insurance Sector Development and Economic Growth in Nigeria, 1980 -2014

\begin{tabular}{|c|c|c|c|c|}
\hline \multirow{3}{*}{ Test critical values: } & \multicolumn{2}{|l|}{$1 \%$ level } & \multicolumn{2}{|l|}{-3.661661} \\
\hline & \multirow{2}{*}{\multicolumn{2}{|c|}{$\begin{array}{l}5 \% \text { level } \\
10 \% \text { level }\end{array}$}} & \multicolumn{2}{|l|}{-3.52174} \\
\hline & & & \multicolumn{2}{|l|}{-2.619160} \\
\hline \multicolumn{5}{|c|}{ *MacKinnon (1996) one-sided p-values. } \\
\hline \multicolumn{5}{|c|}{ Augmented Dickey-Fuller Test Equation } \\
\hline \multicolumn{5}{|c|}{ Dependent Variable: D(GDP,2) } \\
\hline \multicolumn{5}{|c|}{ Method: Least Squares } \\
\hline \multicolumn{5}{|c|}{ Date: $11 / 10 / 15$ Time: 12:43 } \\
\hline \multicolumn{5}{|c|}{ Sample (adjusted): 19802014} \\
\hline \multicolumn{5}{|c|}{ Included observations: 33 after adjustments } \\
\hline Variable & Coefficient & Std. Error & t-Statistic & Prob. \\
\hline $\mathrm{D}(\mathrm{GDP}(-1))$ & -0.592147 & 0.137025 & -3.04811 & 0.0002 \\
\hline C & 12334.69 & 4904.258 & 2.517138 & 0.0176 \\
\hline R-squared & 0.391715 & \multicolumn{2}{|c|}{ Mean dependent var } & -1751.752 \\
\hline Adjusted R-squared & 0.370740 & \multicolumn{2}{|c|}{ S.D. dependent var } & 25704.09 \\
\hline S.E. of regression & 20390.00 & \multicolumn{2}{|c|}{ Akaike info criterion } & 22.74582 \\
\hline Sum squared resid & $1.21 \mathrm{E}+10$ & \multicolumn{2}{|c|}{ Schwarz criterion } & 22.83833 \\
\hline Log likelihood & -350.5602 & \multicolumn{2}{|c|}{ Hannan-Quinn criter. } & 22.77598 \\
\hline F-statistic & 18.67505 & \multicolumn{2}{|c|}{ Durbin-Watson stat } & 0.905610 \\
\hline Prob(F-statistic) & 0.000166 & & & \\
\hline
\end{tabular}

Source: Computed from EView 7.0 (2016)

\section{ADF: Premium}

Null Hypothesis: $D(P)$ has a unit root

Exogenous: Constant

Lag Length: 0 (Automatic - based on SIC, maxlag=8)

\begin{tabular}{llll}
\hline \hline & & t-Statistic & Prob.* \\
\hline \hline Augmented Dickey-Fuller test statistic & 3.4257780 & 0.0019 \\
\hline Test critical values: & 1\% level & -3.661661 & \\
& 5\% level & 1.275433 & \\
& 10\% level & -2.619160 & \\
\hline \hline
\end{tabular}

*MacKinnon (1996) one-sided p-values.

Augmented Dickey-Fuller Test Equation

Dependent Variable: $D(P, 2)$

Method: Least Squares

Date: $11 / 10 / 15$ Time: $12: 43$

Sample (adjusted): 19802014

Included observations: 33 after adjustments

\begin{tabular}{|c|c|c|c|c|}
\hline Variable & Coefficient & Std. Error & t-Statistic & Prob. \\
\hline$D(P(-1))$ & -0.592147 & 0.137025 & 3.4257780 & 0.0002 \\
\hline C & 12334.69 & 4904.258 & 2.517138 & 0.0176 \\
\hline R-squared & 0.411715 & \multicolumn{2}{|c|}{ Mean dependent var } & -1861.712 \\
\hline Adjusted R-squared & 0.310740 & \multicolumn{2}{|c|}{ S.D. dependent var } & 25704.09 \\
\hline
\end{tabular}


Insurance Sector Development and Economic Growth in Nigeria, 1980 -2014

$\begin{array}{llll}\text { S.E. of regression } & 20210.00 & \text { Akaike info criterion } & 22.74582 \\ \text { Sum squared resid } & 1.31 \mathrm{E}+10 & \text { Schwarz criterion } & 22.83833 \\ \text { Log likelihood } & -350.5002 & \text { Hannan-Quinn criter. } & 22.77598 \\ \text { F-statistic } & 12.67505 & \text { Durbin-Watson stat } & 0.905610 \\ \text { Prob(F-statistic) } & 0.000176 & & \end{array}$

Source: Computed from EView 7.0 (2016)

\section{ADF: Investment}

Null Hypothesis: $D(I)$ has a unit root

Exogenous: Constant

Lag Length: 0 (Automatic - based on SIC, maxlag=8)

\begin{tabular}{llll}
\hline \hline & & t-Statistic & Prob. $^{*}$ \\
\hline \hline Augmented Dickey-Fuller test statistic & -3.524701 & 0.0113 \\
\hline Test critical values: & 1\% level & -3.661661 & \\
& 5\% level & -4.935787 & \\
& 10\% level & -2.619160 & \\
\hline \hline
\end{tabular}

*MacKinnon (1996) one-sided p-values.

Augmented Dickey-Fuller Test Equation

Dependent Variable: $\mathrm{D}(1,2)$

Method: Least Squares

Date: 11/10/15 Time: 12:43

Sample (adjusted): 19802014

Included observations: 33 after adjustments

\begin{tabular}{lllll}
\hline \hline Variable & Coefficient & Std. Error & t-Statistic & Prob. \\
\hline \hline $\mathrm{D}(\mathrm{I}(-1))$ & -0.5877647 & 0.137025 & -3.524701 & 0.0001 \\
$\mathrm{C}$ & 09772.69 & 4324.258 & 2.518738 & 0.0197 \\
\hline \hline R-squared & 0.779815 & Mean dependent var & -1411.712 \\
Adjusted R-squared & 0.650880 & S.D. dependent var & 25014.09 \\
S.E. of regression & 22110.00 & Akaike info criterion & 22.74582 \\
Sum squared resid & $1.31 \mathrm{E}+10$ & Schwarz criterion & 22.83833 \\
Log likelihood & -350.5002 & Hannan-Quinn criter. & 22.77598 \\
F-statistic & 11.07705 & Durbin-Watson stat & 2.977600 \\
Prob(F-statistic) & 0.000026 & & \\
\hline \hline
\end{tabular}

Source: Computed from EView 7.0 (2016)

ADF: Claims

Null Hypothesis: $D(C)$ has a unit root

Exogenous: Constant

Lag Length: 0 (Automatic - based on SIC, maxlag=8)

\begin{tabular}{llll}
\hline \hline & & t-Statistic & Prob. $^{*}$ \\
\hline \hline Augmented Dickey-Fuller test statistic & -3.04811 & 0.0019 \\
\hline Test critical values: & 1\% level & -3.661661 & \\
& 5\% level & -3.52174 & \\
& 10\% level & -2.619160 &
\end{tabular}




\begin{tabular}{|c|c|c|c|c|}
\hline $\begin{array}{l}\text { *MacKinnon (1996) } \\
\text { Augmented Dickey-F } \\
\text { Dependent Variable: } \\
\text { Method: Least Squar } \\
\text { Date: 03/02/15 Tim } \\
\text { Sample (adjusted): } 1 \\
\text { Included observation }\end{array}$ & $\begin{array}{l}\text {-sided } p \text {-valu } \\
\text { r Test Equat } \\
c, 2) \\
2014 \\
2014 \text { after adjus }\end{array}$ & tments & & \\
\hline Variable & Coefficient & Std. Error & t-Statistic & Prob. \\
\hline $\begin{array}{l}D(C(-1)) \\
C\end{array}$ & $\begin{array}{l}-0.592147 \\
12334.69\end{array}$ & $\begin{array}{l}0.137025 \\
4904.258\end{array}$ & $\begin{array}{l}-3.889301 \\
2.517138\end{array}$ & $\begin{array}{l}0.0002 \\
0.0176\end{array}$ \\
\hline R-squared & 0.391715 & \multicolumn{2}{|c|}{ Mean dependent var } & -1751.752 \\
\hline Adjusted R-squared & 0.370740 & \multicolumn{2}{|c|}{ S.D. dependent var } & 25704.09 \\
\hline S.E. of regression & 20390.00 & \multicolumn{2}{|c|}{ Akaike info criterion } & 22.74582 \\
\hline Sum squared resid & $1.21 \mathrm{E}+10$ & \multicolumn{2}{|c|}{ Schwarz criterion } & 22.83833 \\
\hline Log likelihood & -350.5602 & \multirow{2}{*}{\multicolumn{2}{|c|}{$\begin{array}{l}\text { Hannan-Quinn criter. } \\
\text { Durbin-Watson stat }\end{array}$}} & 22.77598 \\
\hline F-statistic & 18.67505 & & & 0.905610 \\
\hline Prob(F-statistic) & 0.000166 & & & \\
\hline
\end{tabular}

Source: Computed from EView 7.0 (2016)

\section{Johansen Cointegration Test}

Date: 05/11/16 Time: 12:45

Sample (adjusted): 19802014

Included observations: 33 after adjustments

Trend assumption: Linear deterministic trend

Series: GDP P I C

Lags interval (in first differences): 1 to 1

Unrestricted Cointegration Rank Test (Trace)

\begin{tabular}{lllll}
\hline \hline $\begin{array}{l}\text { Hypothesized } \\
\text { No. of CE(s) }\end{array}$ & Eigenvalue & $\begin{array}{l}\text { Trace } \\
\text { Statistic }\end{array}$ & $\begin{array}{l}0.05 \\
\text { Critical Value }\end{array}$ & Prob.** $^{*}$ \\
\hline \hline None $^{*}$ & 0.988129 & 18.78584 & 15.49471 & 0.0154 \\
At most 1 & 0.920534 & 4.637397 & 3.841466 & 0.0565 \\
At most 2 & 0.798822 & 3.97721 & 3.98826 & 0.0012 \\
At most 3 & 0.446502 & 6.07221 & 4.88667 & 0.0011 \\
Unrestricted & & & & \\
Cointegration & & & & 0.0001 \\
Rank & Test & 7.87752 & 5.87221 & \\
(Trace) & & & & \\
\hline \hline
\end{tabular}

Trace test indicates 1 cointegrating eqn(s) at the 0.05 level

* denotes rejection of the hypothesis at the 0.05 level

**MacKinnon-Haug-Michelis (1999) p-values

Unrestricted Cointegration Rank Test (Maximum Eigenvalue)

\begin{tabular}{lllll}
\hline \hline $\begin{array}{l}\text { Hypothesized } \\
\text { No. of CE(s) }\end{array}$ & Eigenvalue & $\begin{array}{l}\text { Max-Eigen } \\
\text { Statistic }\end{array}$ & $\begin{array}{l}0.05 \\
\text { Critical Value }\end{array}$ & Prob.** \\
\hline \hline None ${ }^{*}$ & 0.396463 & 15.14844 & 14.26460 & 0.0362
\end{tabular}


Insurance Sector Development and Economic Growth in Nigeria, 1980 -2014

\begin{tabular}{|c|c|c|c|c|}
\hline At most 1 & 0.114184 & 3.637397 & 3.841466 & 0.0565 \\
\hline \multicolumn{5}{|c|}{ Max-eigenvalue test indicates 1 cointegrating eqn(s) at the 0.05 level } \\
\hline \multicolumn{5}{|c|}{ * denotes rejection of the hypothesis at the 0.05 level } \\
\hline \multicolumn{5}{|c|}{ **MacKinnon-Haug-Michelis (1999) p-values } \\
\hline \multicolumn{5}{|c|}{ Unrestricted Cointegrating Coefficients (normalized by $b^{\prime *} S 11^{*} b=\mathrm{l}$ ): } \\
\hline GDP & $P$ & I & $\mathrm{C}$ & \\
\hline $1.74 \mathrm{E}-05$ & 0.75532 & 2.9211 & 3.1123 & \\
\hline $1.38 \mathrm{E}-05$ & 2.98811 & 0.83211 & 2.7662 & \\
\hline \multicolumn{5}{|c|}{ Unrestricted Adjustment Coefficients (alpha): } \\
\hline $\mathrm{D}(\mathrm{GDP})$ & -3832.040 & 4239.209 & & \\
\hline$D(P)$ & -3832.040 & 4231.009 & & \\
\hline $\mathrm{D}(\mathrm{I})$ & -3832.040 & 8311.332 & & \\
\hline $\mathrm{D}(\mathrm{C})$ & -3832.040 & 2011.121 & & \\
\hline \multicolumn{2}{|c|}{1 Cointegrating Equation(s): } & Log likelihood & -548.4189 & \\
\hline \multicolumn{5}{|c|}{ Normalized cointegrating coefficients (standard error in parentheses) } \\
\hline & GDP & $\mathrm{P}$ & 1 & $\mathrm{C}$ \\
\hline \multirow[t]{2}{*}{1.000000} & -0.011451 & 1.000000 & -0.011451 & 0.21339 \\
\hline & $(0.00144)$ & & $(0.00144)$ & \\
\hline \multicolumn{5}{|c|}{ Adjustment coefficients (standard error in parentheses) } \\
\hline & $(0.11656)$ & & & \\
\hline \multirow[t]{2}{*}{$\mathrm{D}(\mathrm{GDP})$} & 5.807328 & & & \\
\hline & $(3.98456)$ & & & \\
\hline \multirow[t]{2}{*}{$D(P)$} & -0.821767 & & & \\
\hline & $(0.11932)$ & & & \\
\hline \multirow[t]{2}{*}{$D(I)$} & 5.807328 & & & \\
\hline & $(2.99016)$ & & & \\
\hline $\mathrm{D}(\mathrm{C})$ & (3.11786) & & & \\
\hline
\end{tabular}

Source: Computed from EView 7.0 (2016)

Parsimonious Error Correction Mechanism

Dependent Variable: D(GDP)

Method: Least Squares

Date: 05/11/16 Time: 03:48

Sample (adjusted): 19802014

Included observations: 33 after adjustments

\begin{tabular}{lllll}
\hline \hline Variable & Coefficient & Std. Error & t-Statistic & Prob. \\
\hline \hline$C$ & 0.042386 & 0.027835 & 1.522733 & 0.1399 \\
$D(G D P(-1))$ & 0.988328 & 0.326593 & 3.026178 & 0.0055 \\
$D(G D P(-2))$ & 1.042737 & 0.324291 & 3.215436 & 0.0035 \\
$D(P(-1))$ & 0.206337 & 0.122299 & 2.687151 & 0.0035 \\
$D(P(-2))$ & -0.202906 & 0.121815 & 2.687151 & 0.0078 \\
$D(I(-1))$ & 5.187837 & 6.187739 & 3.687221 & 0.0005 \\
$D(I(-2))$ & 22.86337 & 6.198335 & 5.672111 & 0.0078 \\
$D(C(-1))$ & 7.110037 & 3.866321 & 2.755387 & 0.0071 \\
$D(C(-2))$ & 5.202906 & 2.120015 & 2.755387 & 0.0001
\end{tabular}


Insurance Sector Development and Economic Growth in Nigeria, 1980 -2014

\begin{tabular}{llll}
\hline \hline R-squared & 0.828304 & Mean dependent var & -0.017812 \\
Adjusted R-squared & 0.799132 & S.D. dependent var & 0.138210 \\
S.E. of regression & 2.123686 & Akaike info criterion & -1.174782 \\
Sum squared resid & 1.397753 & Schwarz criterion & -0.899957 \\
Log likelihood & 24.79652 & Hannan-Quinn criter. & -1.083686 \\
F-statistic & 2.541602 & Durbin-Watson stat & 2.825260 \\
Prob(F-statistic) & 0.053169 & & \\
\hline \hline
\end{tabular}

Source: Computed from EView 7.0 (2016)

Normality Test: Jaque-Berra

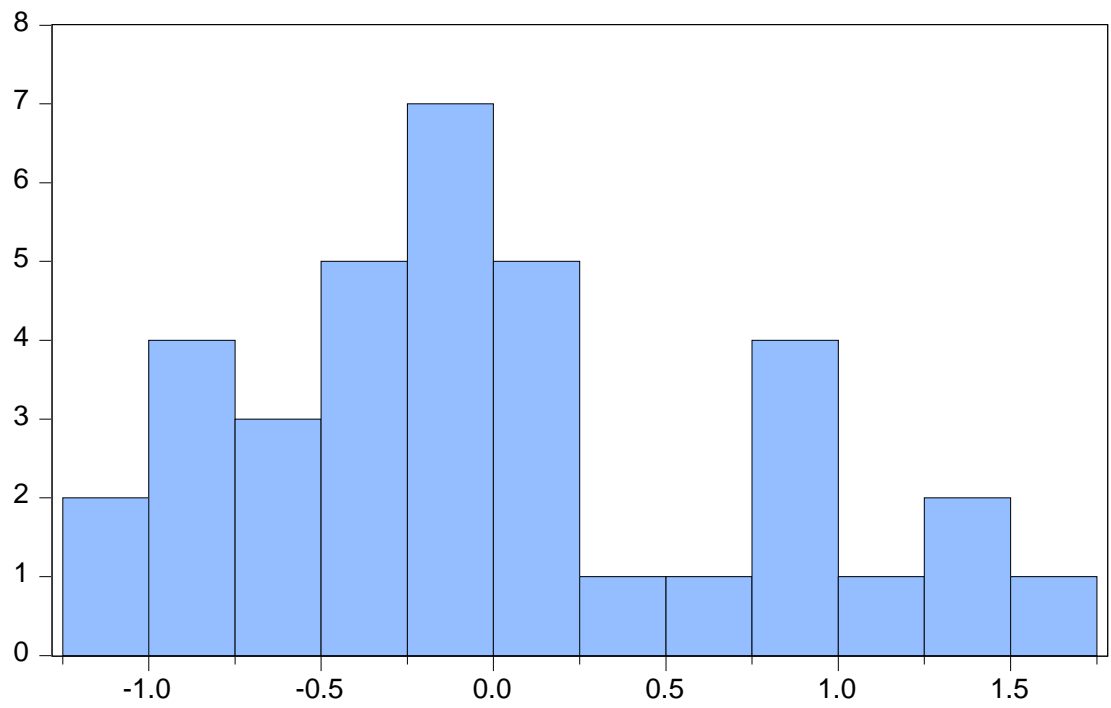

Series: Residuals

Sample 19802014

Observations 34

Mean

$-3.11 e-16$

Median

$-0.126232$

Maximum

Minimum

1.546241

Std. Dev.

$-1.032813$

Skewness

0.715182

Kurtosis

0.000898

2.286105

Jarque-Bera $\quad 2.269864$

Probability $\quad 0.001444$

Granger Causality Test

Pairwise Granger Causality Tests

Date: 04/18/16 Time: 05:15

Sample: 19802014

Lags: 2

\begin{tabular}{lccc}
\hline \hline Null Hypothesis: & Obs & F-Statistic & Prob. \\
\hline \hline $\begin{array}{l}\text { P does not Granger Cause GDP } \\
\text { GDP does not Granger Cause P }\end{array}$ & 34 & $\begin{array}{l}7.83351 \\
0.05910\end{array}$ & $\begin{array}{l}0.0000 \\
0.9427\end{array}$ \\
\hline \hline I does not Granger Cause GDP & 34 & 2.01037 & 0.0363 \\
GDP does not Granger Cause I & & 0.07831 & 0.9249 \\
\hline \hline C does not Granger Cause GDP & 34 & 0.38894 & 0.7266 \\
GDP does not Granger Cause C & & 0.11906 & 0.1222 \\
\hline \hline P does not Granger Cause C & 34 & 0.18273 & 0.8339 \\
C does not Granger Cause P & & 1.31990 & 0.2827 \\
\hline \hline P does not Granger Cause I & 34 & 7.28827 & 0.0027 \\
I does not Granger Cause P & & 2.67152 & 0.0861 \\
\hline \hline C does not Granger Cause I & 34 & 0.12982 & 0.5126 \\
I does not Granger Cause C & & 1.41513 & 0.2592 \\
\hline \hline
\end{tabular}

